\title{
SELECTIVE ORGANIC SYNTHESIS FOR SUSTAINABLE DEVELOPMENT"
}

\author{
Fliur Macaev \\ Institute of Chemistry of the Academy of Sciences of Moldova, \\ Academy str. 3, MD-2028, Chisinau, Moldova \\ Tel +373-22-739-754, Fax +373-22-739-954, E-mail: flmacaev@cc.acad.md
}

\section{Dedicated to academician Gheorghe Duca on the occasion of his $60^{\text {th }}$ birthday}

\begin{abstract}
The data on the development of selective organic synthesis suitable for obtaining multifunctional organic Compounds both linear and cyclic structures using environmentally benign, inexpensive and renewable resources summarized.
\end{abstract}

Keywords: natural chiral hydrocarbons, ionic liquids.

\section{Content}

1. Introduction

2. Natural Compounds derived Chiral Phosphites for Asymmetric synthesis

3. Natural Compounds derived chiral oxindoles with anti-HIV-1 activity

4. New 5-Aryl-2-thio-1,3,4-Oxadiazoles with Antituberculosis Activity Oxadiazole

5. New binary systems of $\beta$-cyclodextrin with a highly potential anti-mycobacterial 5-Aryl-2-thio-1,3,4-

6. Green chemistry protocols

6.1. Ionic liquids as recyclable solvents/catalysts

6.2. Ionic liquids as recyclable catalysts

6.3. New Solvents/catalysts from renewable resources

7. Conclusions

8. Acknowledgments

9. References

\section{Introduction}

Sustainable development is a pattern of resource use, which aims to meet human needs while preserving the environment so that these needs can be met not only in the present, but also for generations [1]. Chemistry has taken on a crucial role in science and society. Since the early days the stereoselective organic synthesis has remained an important branch of chemistry. Progress of modern synthetic organic chemistry is defined by two general tendencies profound study of biological processes and natural products as the ground for creation of new effective bioregulators (drugs, pharmaceuticals, diagnostic materials, pesticides et al.) and the use of natural substances as the starting materials (raw materials) for synthesis of new optically active compounds including bioregulators [2-6]. This development reflected a growing need for an efficient synthetic methodology to produce enantio-enriched organic compounds finding application as pharmaceuticals, agrochemicals, flavours and fragrances, etc. It is knowledge that the configuration of the chiral compound often has a profound effect on its biological activity. In the pharmaceutical industry the current trend aims at developing single enantiomer drugs in the areas, where racemates are still in use, which clearly calls for the methodology for the preparation of the required active isomers in the enantiomerically pure form. One of the ways of achieving this target relies on the use of chiral pool of readily available and renewable stock of natural products or uses them as chiral promoter [7-52]. Based on the biological importance of chirality, pharmaceutical, agrochemical, flavour and fragrance industries invest heavily into development of asymmetric technologies where chiral pool reagents play a significant role. A family of chiral monoterpenes incorporating pinenes 1, 2 and carene 3, due to their natural chirality and advanced skeleton, serve as a feedstock for asymmetric synthesis [53-61].

\footnotetext{
" This article is an extended abstract of a communication presented at the Conference Ecological Chemistry 2012
} 


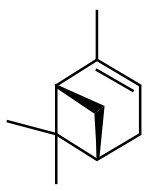

1

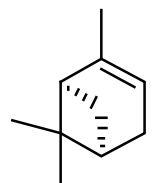

2

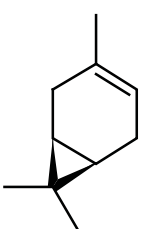

3

Figure 1

Importantly, nature produces these compounds in both enantiomeric series, which favorably compares with other natural sources of chirality such as amino acids and sugars, occurring predominantly in only one enantiomeric form.

Sustainable chemistry is the design, manufacture and use of environmentally benign chemical products and processes to prevent pollution produce less hazardous waste and reduce environmental and human health risks.

\section{Natural Compounds derived Chiral Phosphites for Asymmetric synthesis}

Current trends in organic synthesis shown that asymmetric synthesis has become a primary focus of activity for many of the leading researchers in both academic and industrial worlds [62]. The tragedy of the thalidomide babies emphasized the importance of achieving the synthesis of optically pure drugs. Optical resolution as a method to prepare optically pure compounds is often uneconomical and impractical. Frequently the most desirable method for synthesizing optically pure materials is asymmetric synthesis.

Optically active phosphite-type compounds are very attractive and promptly developing class of phosphoruscontaining ligands. As a whole, the most important advantages of chiral phosphites include their pronounced $\pi$-acidity, oxidation stability, as well as their synthetic availability and low cost. In particular, phosphites provide broad opportunities for fine tuning of their donor-acceptor and steric properties by incorporation of oxygen and nitrogen into the first coordination sphere of phosphorus and wide variation of the $\mathrm{O}$ - and/or N-containing building blocks. Most of phosphites can be synthesized rather simply and in high yield from a variety of optically active precursors. This makes it possible to perform the direct one-pot phosphorylation of chiral compounds, whereas the synthesis of the corresponding phosphine derivatives requires preliminary modification. In addition, these compounds exhibit higher oxidative stability because of the absence of P-C bonds. So, this makes it possible to develop protocols for the whole process that do not necessitate the use of a glovebox, including the ligand synthesis.

We designed and synthesized a library of novel $P^{*}$-chiral monodentate phosphite ligands 4-10 having fivemembered phosphacycles and OMe or $\mathrm{NEt}_{2}$ exocyclic substituents [63-65]. These can be easily prepared by direct phosphorylation of the appropriate bifunctional compounds and purified by vacuum distillation. They possess modular properties, allowing fine-tuning of their steric and electronic characteristics. The starting optically active diols 5-7, were synthesised from pinene as well as (+)-2- and 3-carenes.

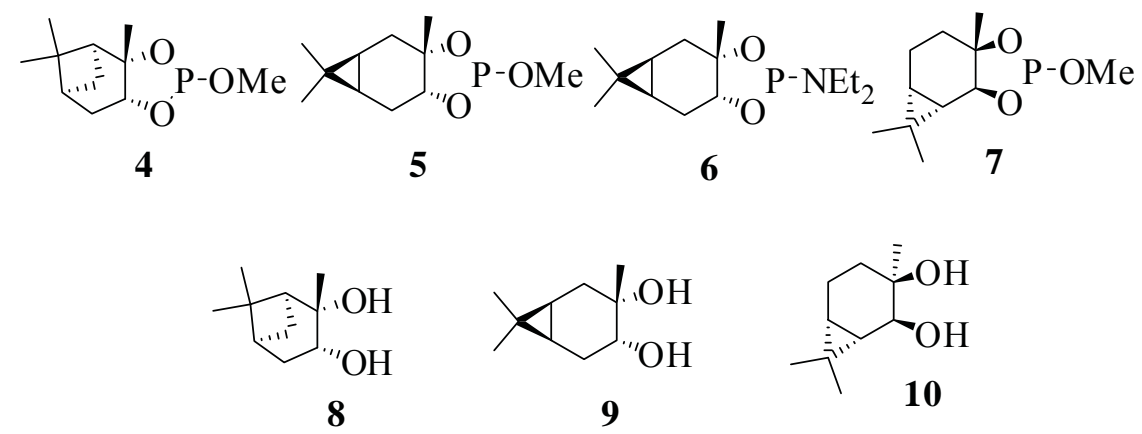

Figure 2

3-Carene-based compounds 5,6 are characterized by rather small contents of the minor epimer. In the last case, the major stereoisomer has the $R$ - configuration at the $P^{*}$ - stereocenter. Another approach to enhance the asymmetrising activity of $P^{*}$-chiral phosphite-type compounds is the synthesis of the respective $P, N$-bidentate ligands with additional $C^{*}$ - stereocenters in the peripheral $N$-containing group. In particular, oxazolinophosphite $\mathbf{1 1}$ has been prepared using phosphoramidite $\mathbf{6}$ as a phosphorylating reagent (scheme 1). 


\section{Scheme 1}
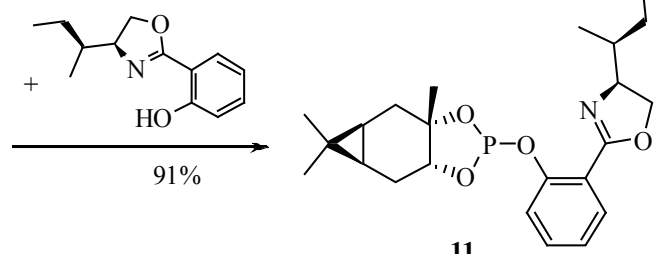

The synthesis of the novel phosphite is highly diastereoselective. The new ligands are stable enough to allow manipulation in open air and can be stored under a dry atmosphere for several months without degradation. It is noteworthy that owing to the easiness of each step, as well as the easy-to-handle nature of all the related intermediates, diamidophosphites can be prepared on multigram scales. Ligands based on terpene alcohol, induce high enantioselectivities (ee's up to 99\%) in Pd-catalyzed allylic substitution reactions (scheme 2).

\section{Scheme 2}

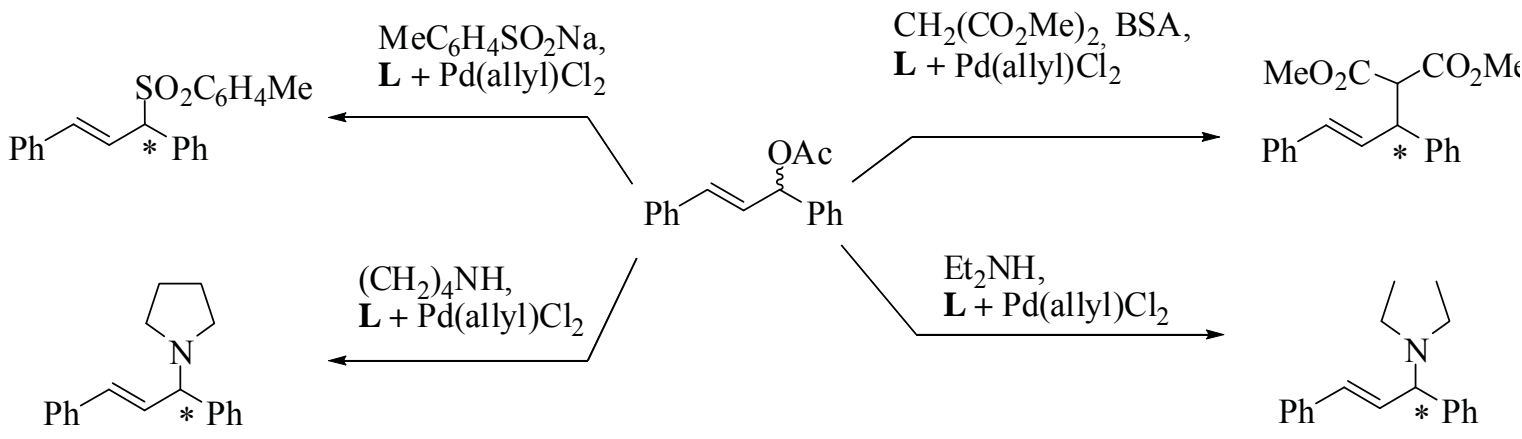

\section{Natural compounds derived chiral oxindoles with anti-HIV-1 activity}

The twentieth century has been characterized both by a drastic reduction in the mortality caused by infectious diseases and by a rise in the control of neoplastic pathologies [6]. The treatment of infectious diseases still remains an important and challenging problem. The therapeutic problem has achieved increasing importance in hospitalised patients, in immuno suppressed patients with AIDS or undergoing anticancer therapy and organ transplants. A decade ago we initiated a program on synthesis of chiral oxindoles. In this account we are discussing our progress in field of antiviral activity evaluation of new oxindoles 12-21, 27-29 and an enantio-pure analogues 22-26 [2,66-69].<smiles>[R4]C(=O)C[C@]1(O)C(=O)N([R])c2ccccc21</smiles>

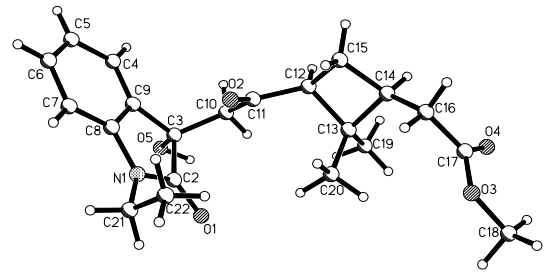<smiles>CC(=O)N1C(=O)/C(=N\NC(N)=S)c2ccccc21</smiles>

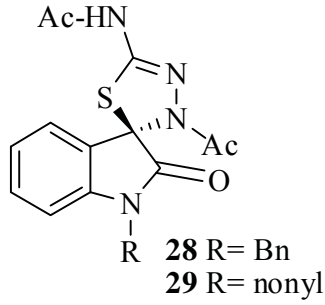

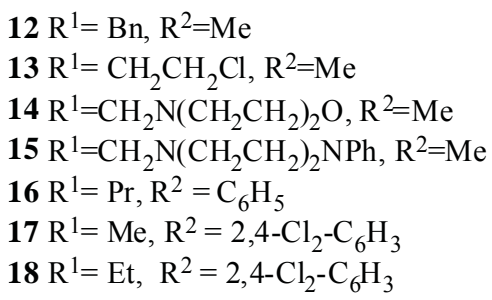

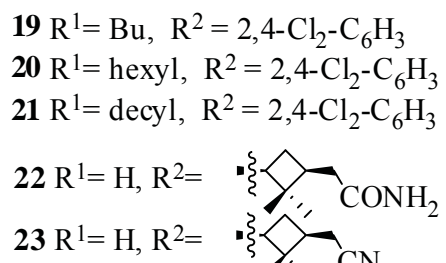

Figure 3 
The synthesized compounds exhibited different cytotoxicity, in particular, oxindols 12, 13, 14,15, 16, 17, 18, 19, 20, 21 turned out to be the most cytotoxic for MT-4 cell lines. The compounds 19 and 25, are more toxic than reference compound Efavirenz. As far as the antiviral activity is concerned, none of the title compounds turned out active against Reo-1, Sb-1, VSV, RSV, YFV and VV viruses. The results obtained against Bovine Viral Diarrhoea Virus (BVDV) showed that six compounds 14, 20, 21, 24, 27, 28, 29 resulted moderate active. Among all of them, the most potent compound was 27, with $\mathrm{EC}_{50}$ of $6.6 \mu \mathrm{M}$. Studies of effect of synthesized compounds against Coxsakie Virus (CVB-2) revealed that only compound 21 exhibit moderate activity $\left(\mathrm{EC}_{50}>40 \mu \mathrm{M}\right)$. It should be noticed that compounds, 12, 13, 15, 16, 17, 18, 19, 20, 21, 22 and 29 showed moderate activity against $\mathrm{HIV}-1\left(\mathrm{EC}_{50}>16-\mathrm{m}>59 \mu \mathrm{M}\right)$.

\section{New 5-Aryl-2-thio-1,3,4-Oxadiazoles with Antituberculosis Activity}

Tuberculosis remains the number one killer infectious disease affecting adults in developing countries. TB is a global emergency. The situation is more complicated when one considers countries such as India where TB disproportionately affects the young. India accounts for one-third of the global TB burden, with 1.8 million developing the disease each year and nearly 0.4 million dying due to TB annually.Until 50 years ago, there were no medicines to cure TB. Now, strains that are resistant to single drugs have been documented in every country surveyed, and, unfortunately, strains of TB resistant to all major anti-TB drugs have emerged. Drug-resistant TB is caused by many factors: inconsistent or partial treatment and lack of compliancy (sometimes patients do not take all their medicines regularly for the required period because they start to feel better), prescription of wrong treatment regimens, or unreliable drug supply. A particularly dangerous form of TB is that caused by multidrug-resistant TB (MDR-TB), defined as bacilli resistant to at least isoniazid and rifampicin, the two most powerful anti-TB drugs. While drug-resistant TB is generally treatable, it requires extensive chemotherapy (up to two years of treatment) that is often prohibitively expensive (often more than 100 times more expensive than treatment of drug-susceptible TB), in addition to being more toxic to patients. Noteworthy, the development of drug resistance also involves other poverty-related diseases, such as malaria and HIV / AIDS. 1,3,4-oxadiazoles form an important class of five-member heterocyclic compounds with a wide range of biological activities. The importance of the oxadiazoles' nucleus is well established in agricultural and pharmaceutical chemistry as far as its corresponding derivatives are used as antipyretic, analgesic, antidepressant, antimicrobial, antiviral, fungicidal, antineoplasic, anti-inflammatory agents, central nervous system stimulants, and anticonvulsive, anticancer, and antihypertensive agents. Their important structural characteristic is the presence of two aromatic rings spaced by a heteroatom.

The knowledge of quantitative relationships between chemical structure and biological activity is an essential prerequisite for the effective search for biologically active compounds. Earlier our group reported that a number of 2,5-disubstituted-1,3,4-oxadiazoles have good anti-tuberculosis activity against M. tuberculosis H37Rv [70]. Shortly a series of 82 5-Aryl-2-thio-1,3,4-oxadiazole derivatives were screened for their antimycobacterial activities against Mycobacterium tuberculosis H37Rv. The synthesis of target 1,3,4-oxadiazoles 29-33 was accomplished by the following synthetic route (scheme 3) [71].

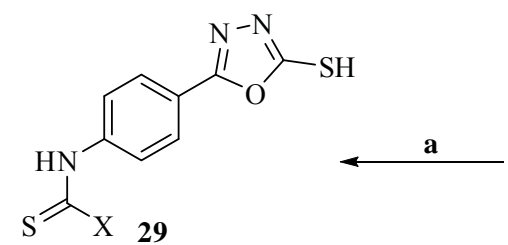<smiles>[R]c1ccc(-c2nnc(S)o2)cc1[R]</smiles><smiles>[X]C(=S)Nc1cccc(-c2nnc(S)o2)c1</smiles>

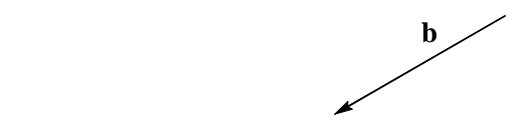

$27 \mathrm{R}^{1}=\mathrm{SCN}, \mathrm{R}^{2}=\mathrm{H}$ $28 \mathrm{R}^{1}=\mathrm{H}, \mathrm{R}^{2}=\mathrm{SCN}$<smiles>[N-]=[N+]=[Mg]</smiles>

31
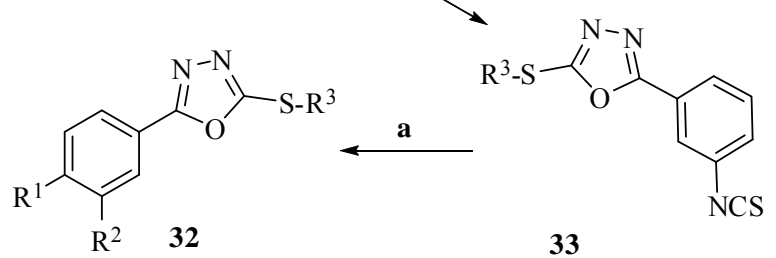

33

a: amines; b: Hal- $\mathrm{R}^{3}, \mathrm{~K}_{2} \mathrm{CO}_{3} / \mathrm{DMF}$ or $\mathrm{Et}_{3} \mathrm{~N} /$ acetone;

$\mathbf{X}=\mathrm{NH}_{2}, \mathrm{NH}-\mathrm{Me}, \mathrm{NH}-\mathrm{Et}$, NH-p-tolyl, $\mathrm{NH}$-allyl, $\mathrm{NH}\left(\mathrm{CH}_{2}\right)_{2} \mathrm{OH}, \mathrm{NHBn}, 4-\mathrm{PyCH}_{2} \mathrm{NH}, \mathrm{ArC}(\mathrm{O}) \mathrm{CH}_{2} \mathrm{NH}$, piperidine, morpholine, 4-amino-1,2,4-triazole, hydrazones 
Due to the presence of two high reactive groups in molecules $\mathbf{2 7 , 2 8}$, the $-\mathrm{SH}$ group alkylation reaction and addition of different nucleophiles to isothiocyanate group can lead to a large number of new compounds. At the outset of this study it was observed that reactions of 2-mercapto-5-(4-isothiocyanatophenyl)-1,3,4-oxadiazole 27 with different amines in refluxing benzene gave corresponding substituted thioureas 29 with $68 \%$ up to $92 \%$ yield. Sulfides 30 can be prepared by treatment of thiol 27 with alkyl halides. Depending on the nature of the alkylating reagent, the synthesis was carried out either in acetone in the presence of $\mathrm{Et}_{3} \mathrm{~N}$ or in DMF in the presence of $\mathrm{K}_{2} \mathrm{CO}_{3}$. Further, reactions of 2-S-substituted-5-[(4)-isothiocyanatophenyl]-1,3,4-oxadiazoles 31,33 with amines have led to thioureas 32 with high yields. The seven synthesized compounds appeared to be the most active derivatives exhibiting more than $90 \%$ inhibition of mycobacterial growth at $12.5 \mu \mathrm{g} / \mathrm{mL}$. Structure-activity relationships study was performed for the given series by using the Electronic-Topological Method combined with Neural Networks (ETM-NN). A system for the anti-mycobacterial activity prediction was developed as the result of training associative neural network (ASNN) with weights calculated from projections of a compound and each pharmacophoric fragment found on the elements of the Kohonen's self-organizing maps (SOM). From the detailed analysis of all compounds under study, the necessary requirements for a compound to possess antituberculosis activity have been formulated. The analysis has shown that any requirement's violation for a molecule implies a considerable decrease or even complete loss of its activity.

Computer-assisted molecular modelling (CAMM) plays an essential role in the design of potential ligands that are both sterically and chemically compatible with the binding site of a target bio-macromolecule. Docking was performed with default settings to obtain a population of possible conformations and orientations for the inhibitors at the binding site. Knowing the binding site conformations helps to show the important interactions that stabilize the complex.

Molecular docking studies of the compounds allowed shedding light on the binding mode of these novel antimycobacterial inhibitors (figure 4).
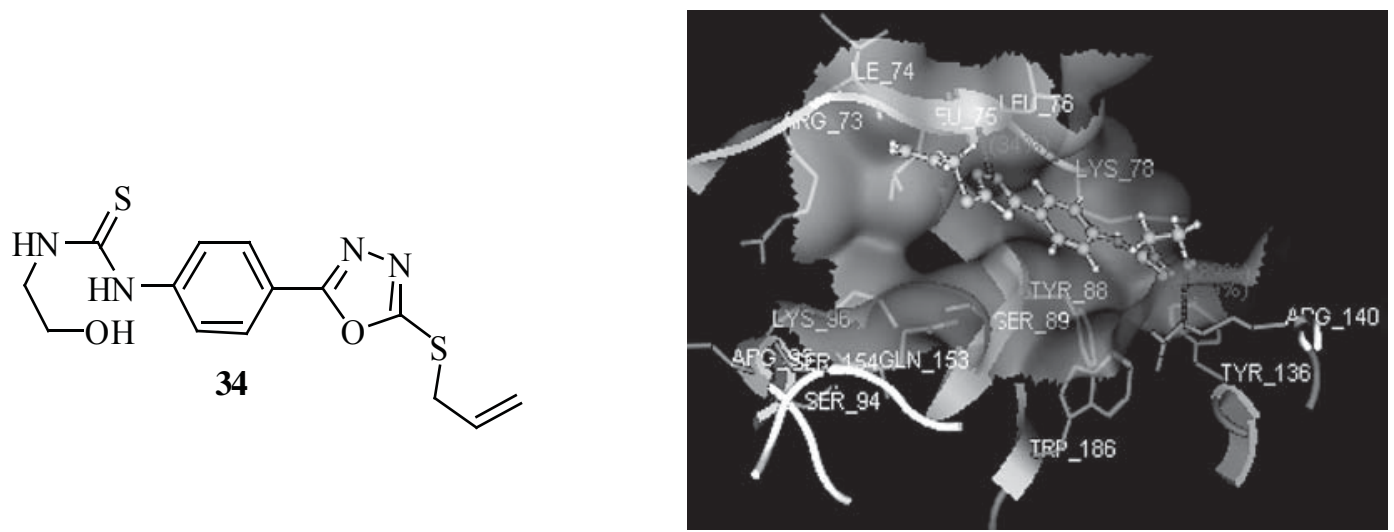

Figure 4

Docking of active compound 34 (figure 4) in Rv1155 shows that this compound docks well in the active site that consists of such amino acids as Ser144, Arg140, Lys78, Tyr88, Ile74, Leu75, and Leu76. The oxygen of the hydroxyl

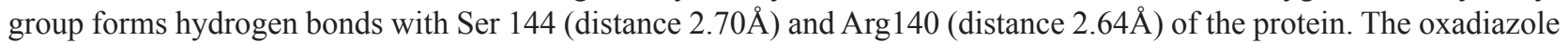
ring is located in the vicinity of amino acids Leu 76 and Leu75. The nitrogen of oxadiazole forms a hydrogen bond with Leu76 (distance 2.65 $\AA$ ). Four of amino acids show a sidechain and backbone acceptor properties. Three of amino acids (Leu75, Leu76 and Ile74) show backbone donor properties. The phenyl ring settles in a hydrophobic cavity lined by Lys78, Tyr88, and Ser89.

\section{New binary systems of $\beta$-cyclodextrin with a highly potential anti-mycobacterial 5-aryl-2-thio-1,3,4- oxadiazole}

The studies performed by our group have lead to discovery of another group of substances with high antimycobacterial activity from the class of 5-aryl-2-thio-1,3,4-oxadiazole derivatives. Among the studied substances, 2-phenyl-5-\{[2-phenyl-1,3-dioxolan-2-yl)methyl]sulfanyl $\}-1,3,4$-oxadiazole (DIOX) (figure 5) has shown the highest level of predicted and in vitro activity [70]. The substance's molecular weight is 340,4 , it has 5 freely rotatable bonds, 5 hydrogen bond acceptors and no hydrogen bond donors that makes it a drug able candidate according to the Lipinski rule [72]. Still, there is one important disadvantage that can influence bioavailability of the drug and reduce its pharmacological activity - a low solubility in water. In order to overcome this shortcoming, it has been proposed to study the possibility of DIOX inclusion in complexes with $\beta$-cyclodextrins. Besides, in the case of the direct contact of the inclusion complex with the M. tuberculosis cell, the presence of cyclodextrins in the formulation may increase permeability of mycobacterial wall for the active substance [73]. 

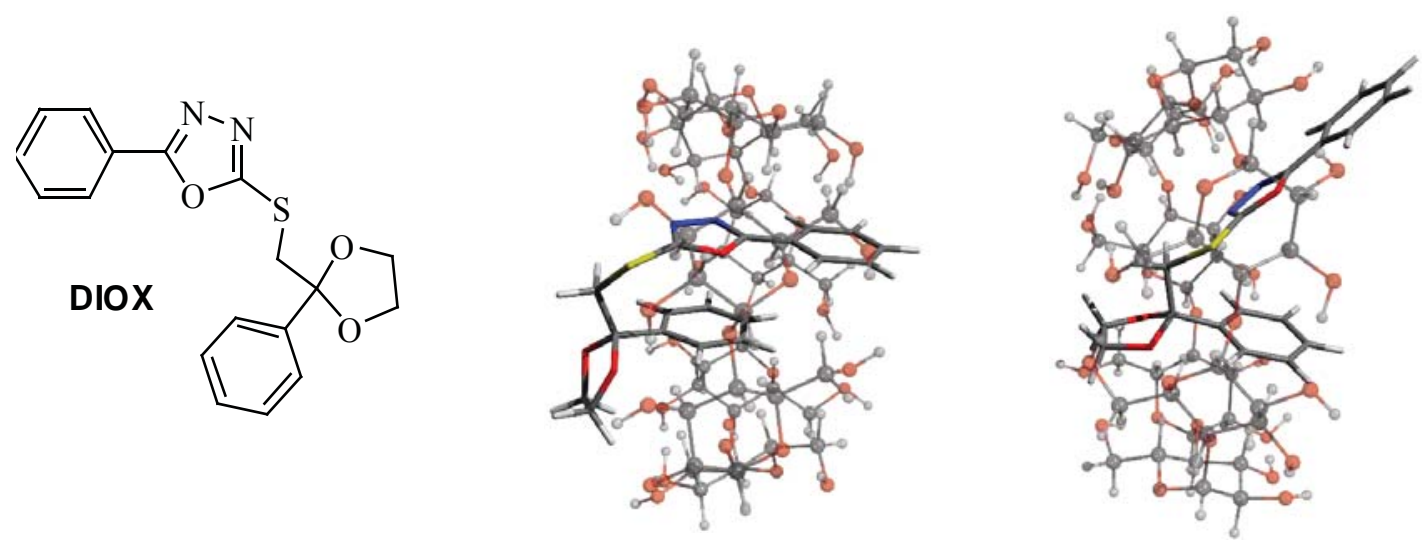

Figure 5

We have shown that 2-phenyl-5-\{[2-phenyl-1,3-dioxolan-2-yl)methyl]sulfanyl $\}-1,3,4$-oxadiazole (DIOX) interacts with $\beta C D$ and the main parts of the DIOX molecule involved in the interaction process are dioxolane and benzene rings [74].

The molecular interaction between DIOX and $\beta C D$ makes possible its future study in new types of antituberculosis treatment where the presence of $\beta C D$ does not only provide better bioavailability and stability characteristics to the active ingredient, but also plays the role of promoter of the active substance transportation through the bacterial cell wall, increasing its permeability for the substance. The latest is possible in the case of direct interaction of the complex with the bacterial cell.

\section{Green chemistry protocols}

Ionic liquids are a relatively new class of compounds that have been receiving increased attention in recent years as "green" designer solvents that may potentially replace many conventional volatile organic solvents in reaction and separation processes. These unique compounds are organic salts that are liquid over a wide range of temperatures near and at room temperature. Ionic liquids have no measurable vapor pressure; hence, there has been considerable interest in using them in place of volatile organic solvents that can emit problematic vapors. The use of Ionic Liquids in organic synthesis often leads to shorter reaction times, increased yields, easier workup, all of which are important considerations for Green Chemistry protocols.

\subsection{Ionic liquids as recyclable solvents/catalysts}

Increased requests to ecologically pure selective chemical processes need to develop a new type of compounds, posses several useful properties (combination of solvent and catalyst for the same compound), and possibility to use of it without any additional regeneration and purification. Ionic liquids (IL) posses all above mentioned properties, but the list of it is very short. Furthermore, the use of ILs may enhance the regio- and stereo-selectivity of reactions. Well known, one of the tasks of the synthesis of a bioactive compound is preparation of required enantiomer in optically pure form. Bicyclic monoterpene (+)-3-carene $\mathbf{3}$ is widely used for resolving this type of problems. A structural future of compound $\mathbf{3}$ is the presence of the reactive $\mathrm{C}=\mathrm{C}$ double bond and bicyclic bridging system. This fact opens perspectives for new synthesis with retention of the bicyclic framework of monoterpene 3.

$(+)-4 a-A c e t y l-2$-carene 35, and (+)-4a-hydroxymethyl-2-carene 36, are widely used to synthesize precursors of commercially important insecticides [54-58]. Known methods for preparing 4-substiututed 2-carenes 35, 36 include heating 2a with $\mathrm{ZnCl}_{2}$ in $\mathrm{Ac}_{2} \mathrm{O}$ solution or with paraformaldehyde in $\mathrm{AcOH}$.

The new type of ionogenic solvents/catalysts for Kondakov's and Prins's reactions was proposed us (scheme 4) [75].

\section{Scheme 4}

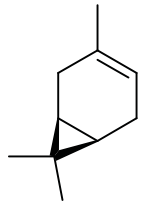

3

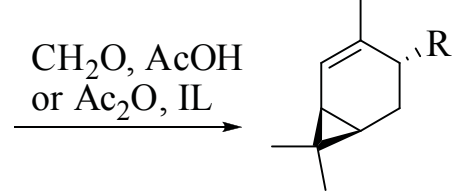

$35 \mathrm{R}=\mathrm{Ac}$ $36 \mathrm{R}=\mathrm{CH}_{2} \mathrm{OH}$

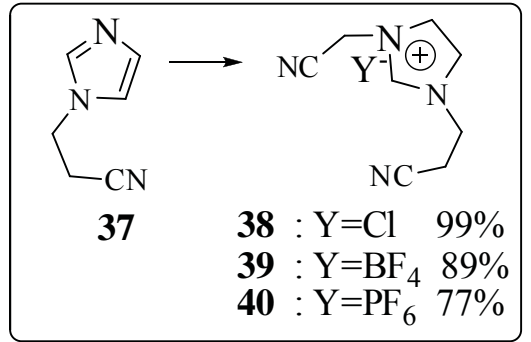


The salt 38 was prepared by quaternization of 37 [75-79]. The next step was the metathesis of imidazolium salt 6 with the appropriate inorganic salt $\left(\mathrm{KPF}_{6}\right.$ or $\left.\mathrm{KBF}_{4}\right)$. It was observed that heating of $(+)$-3-carene 2a, acetic anhydride, or with paraformaldehyde in $\mathrm{AcOH}$ and 6 mole \% 38, 39, or 40 at $+60^{\circ} \mathrm{C}$ afforded the $(+)$-4a-acetyl-2-carene 35 and

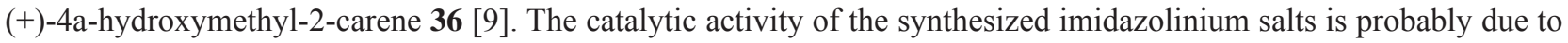
initial formation of an acylium ion from $\mathrm{Ac}_{2} \mathrm{O}$ that involves the nitrile associated with the anion (see scheme 5).

\section{Scheme 5}

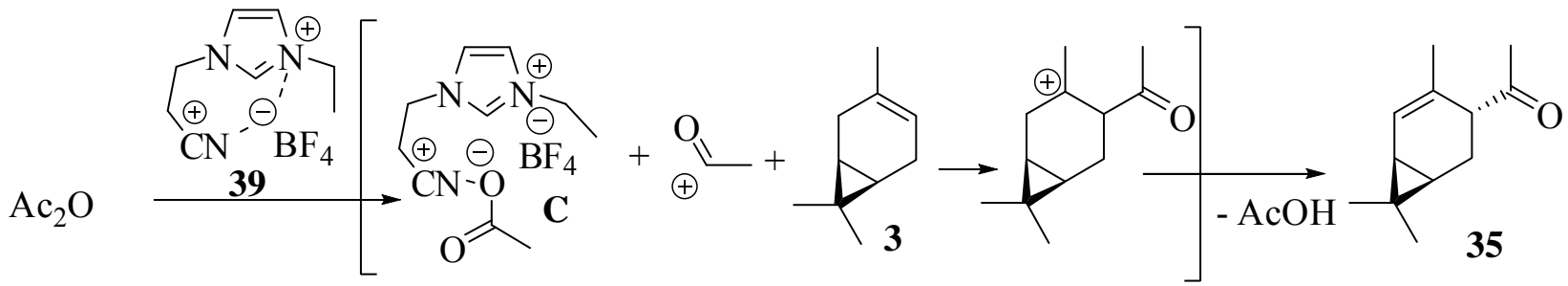

The carbonium ion formed by addition of the acyl-cation to the double bond of (+)-3-carene 2a is stabilized by elimination of a proton to regenerate double bond of (+)-4a-acetyl-2-carene $\mathbf{3 8}$.

On the other side the $\alpha$-hydroxy carbonium ion generated via adding of a proton to formaldehyde reacts with $(+)$-3-carene 3 to give the hydroxyl-carbonium ion that is stabilized via elimination of a proton (scheme 6).

\section{Scheme 6}

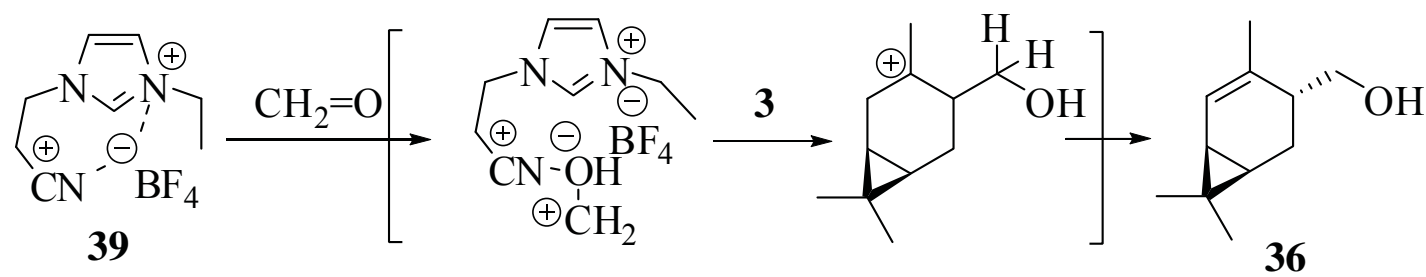

Finally the generations double bond of (+)-4a-hydroxymethyl-2-carene 36 was realizing.

\subsection{Ionic liquids as recyclable catalysts}

The knowledge about the three-component condensation reaction between an aldehyde, a urea or thiourea, and an easily enolizable carbonyl compound, is quite extensive. This reaction offers a straightforward approach to bioactive 3,4-dihydropyrimidin-2-(1H)-ones(thiones).

Recently we reported about the synthesis of the mixture 42a,43a or $\mathbf{4 2 b , 4 3 b}$ from monochloroacetic acid and N-substituted imidazoles 41a,b [80].

\section{Scheme 7}<smiles></smiles>

41a,b<smiles>O=C(O)CCl</smiles><smiles>C1CC1</smiles>

42a,b<smiles></smiles>

$\mathrm{R}=\mathrm{Me}(\mathrm{a}), \mathrm{CH}_{2} \mathrm{CH}_{2} \mathrm{CN}(\mathrm{b})$

Additionally, we have looked for ionic liquids composed of imidazolium cations with "free" carboxyl group. The most logical protocol for the synthesis comprises the use the protected carboxyl group $\alpha$-monohalogenated acetic acid followed by removal of protecting group [81]. 


\section{Scheme 8}<smiles>CCCCC(=O)OC(C)(C)C</smiles><smiles>Cn1cc[n+](CC(=O)O)c1</smiles><smiles></smiles>

The imidazolium bromide $\mathbf{4 4}$ has been prepared by reaction of the appropriate imidazole 41a with tertbutyl bromoacetate, which was subsequently treated with catalytic amount of water solution of $\mathrm{HBr}$ to afford the 3-carboxymethyl-1-methyl-1H-imidazolium bromide 45a. Oily salt 45b was obtained by addition of one equivalent of $98 \% \mathrm{H}_{2} \mathrm{SO}_{4}$ to product 45b. We examined the Biginelli reaction of ethyl acetoacetate with benzaldehyde and urea (or thiourea) in the presence of 42a,b, 43a,b, 45 a or $\mathbf{4 5 b}$ at elevated temperatures (scheme 9).

\section{Scheme 9}<smiles>[X]C(N)=[O+]c1ccccc1</smiles>

42a,b, 43a,b, 45a or $45 \mathrm{~b}(0.6 \mathrm{~mol} \%)$ $105-120^{\circ} \mathrm{C}$<smiles>[X]C1=NC(C)=C(C(=O)OCC)C(c2ccccc2)N1</smiles>

46a : $\mathrm{Ar}=\mathrm{Ph}, \mathrm{X}=\mathrm{O}$

46b : $\mathrm{Ar}=\mathrm{Ph}, \mathrm{X}=\mathrm{S}$

Both reactions gave rise to the corresponding 3,4-dihydropyrimidin-2-(1H)-ones(thiones) 46a,b which were formed in variable yield. The reaction mechanism involves the condensation of urea with the aldehyde at high temperature to yield the corresponding iminium intermediate, which is then trapped by an aldol-type reaction with the enol derived from the ketoester. Such an effect may also be of significance in the action of "free" carboxy group of acetic acid and the enhancement of selectivity in the presence of imidazolium, as well as hydrogensulphate or bromine ions.

The yield, as well as the time of the reaction, was significantly improved by the nature of the catalyst (see Table 1).

Table 1

\begin{tabular}{|c|c|c|c|}
\hline № Compound & Catalyst & Time (min) & Yield (\%) \\
\hline \multirow{5}{*}{ 46a } & 42a,b & 90 & 56 \\
\cline { 2 - 4 } & 43a,b & 60 & 61 \\
\cline { 2 - 4 } & 45a & 30 & 72 \\
\cline { 2 - 4 } & 45b & 10 & 67 \\
\cline { 2 - 4 } & 42a,b & 90 & 55 \\
\cline { 2 - 4 } & 43a,b & 80 & 67 \\
\cline { 2 - 4 } & 45a & 60 & 65 \\
\hline
\end{tabular}

It is worth noting, that our synthesized "ionic liquids" are more effective catalysts in comparison with other early published ones [82,83]. We also observed that all catalysts can be recovered during isolation of products $46 \mathbf{a}$ and $\mathbf{4 6 \mathbf { b }}$.

\subsection{New Solvents/catalysts from renewable resources}

In the current age of high dependency of chemical industries on the resources coming from oil and gas which are getting increasingly scarce, the focus is shifting towards renewable feedstock. In this prospective, natural monoterpenes produced by a wide variety of plants represent a group of inexpensive and abundant starting materials for fine chemical synthesis. It is noteworthy that used specific ionic liquids 38-40 are synthetic chemicals arising from petroleum. As this 
resource continues to be consumed at a prodigious pace, and given the rather turbulent conditions present in some of the major oil-producing parts of the market, alternative materials, possible based on biorenewable monoterpenoids, are of considerable interest and great practical benefit.

Shortly our interest in area of green solvents-catalysts from renewable resources prompted us to focus our attention on the optically active lactams 41-46 from (+)-3-carene 3 and $\alpha$-pinenes 1 or 2 [84] (scheme 10).

\section{Scheme 10}<smiles>CC1=CCC(C)CC1</smiles>

3<smiles></smiles>

49<smiles>CC1=CCC2CC1C2C</smiles>

1,2<smiles>CC1CC2CC3CC(C2)C(NC1=O)C3C</smiles>

47<smiles>CC(C)[C@H]1C[C@H]2NC(=O)[C@H]1C[C@H]2C</smiles>

48

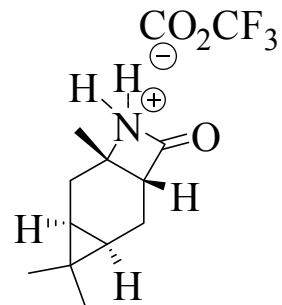

50

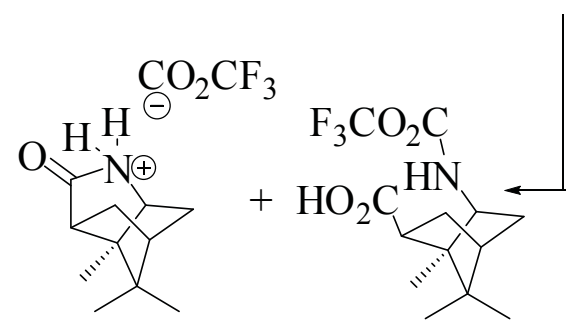

51

52

The stirring of lactams $\mathbf{4 8}$ or $\mathbf{4 9}$ in trifluoroacetic acid at room temperature gave the mixture of trifluoroacetates $\mathbf{5 1 / 5 2}$ or $\mathbf{5 0}$ in quantitative yields. We were proposed use of the lactam-functionalized ionic liquids $\mathbf{5 0}$ and $\mathbf{5 1 / 5 2}$ as catalysts to a synthesis of known [85] ethyl 1,2,6-triphenyl-4-(phenylamino)-1,2,5,6-tetrahydropyridine-3-carboxylate 53 via a solvent free one-pot multicomponent approach (see scheme 11).

\section{Scheme 11}

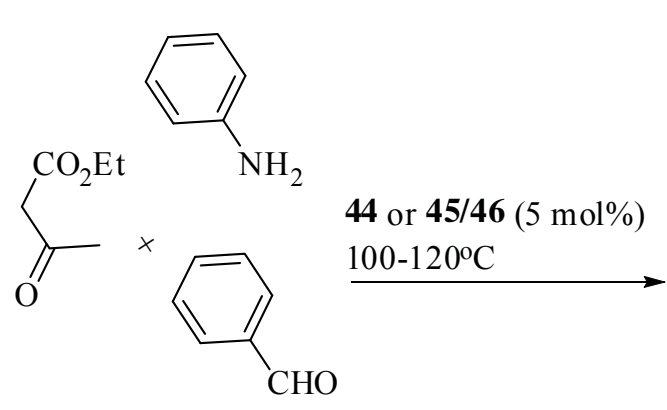<smiles>CCOC(=O)C1=C(Nc2ccccc2)C[C@@H](c2ccccc2)N(c2ccccc2)[C@H]1c1ccccc1</smiles>

In all tested cases the product 53 was obtained with good yields. Slightly higher selectivity has been observed in the reaction between benzaldehyde, ethyl acetoacetate and aniline using mixture 51/52 as a catalyst in comparison with catalysts 50. It should be to note that all catalysts can be recovered during isolation of product 53.

\section{Conclusions}

In the light of the above-mentioned results, we have conclude that development of synthetic pathway suitable for obtaining multifunctional organic compounds both linear and cyclic structures using environmentally benign, inexpensive and renewable resources (ionic liquids, natural chiral hydrocarbons etc) should be continued. The overall objective of such approach is reinforcement of the sustainable chemistry in Moldova according to the contemporary needs of the European chemical and biophamaceutical sector and based on the highest European Research Area (ERA) standards.

\section{Acknowledgements}

I would like to thank my co-workers for their suggestions have made a much better our research. Their names are listed in the references. 


\section{References}

[1]. United Nations. 1987. General Assembly Resolution 42/187, 11 December 1987. Retrieved: 2007-04-12

[2]. Satyamaheshwar, P. Current Bioactive Compounds. 2009, 5, 20-38.

[3]. Secara, N.; Duca, Gh.; Vlad, L.; Macaev, F. Chem. J. Moldova. 2011, 6, 29-44.

[4]. Ribkovskaia, Z.; Pogrebnoi, S.; Barba, A.; Macaev, F. Chem. J. Moldova. 2011, 6, 90-100.

[5]. Radul, O.; Sucman, N.; Pogrebnoi, S.; Barba, A.; Geronikaki, A.; Macaev, F. Chem. J. Moldova. 2011, 6, 101109.

[6]. Tsogoeva, S. B.; Hateley, M. J., Yalalov, D. A.; Meindl, K.; Weckbecker, C.; Huthmacher, K. Bioorg. Med. Chem., 2005, 13, 5680-5685.

[7]. Reetz, M.T.; List, B.; Jaroch, S.; Weinmann, H. Organocatalysis; Springer: Berlin, 2008.

[8]. Dalko, P.I. Enantioselective Organocatalysis; WILEY-VCH Verlag GmbH \& Co. KGaA: Weinheim, 2007.

[9]. Berkessel, A.; Groger, H. Asymmetric Organocatalysis-From Biomimetic Concepts to Applications in Asymmetric Synthesis; WILEY-VCH Verlag GmbH \& Co. KGaA: Weinheim, 2005.

[10]. Ma, J.A.; Cahard, D. Angew. Chem. 2004, 116, 4666-4683.

[11]. Gröger, H. Chem. Eur. J. 2001, 7, 5246-5251.

[12]. Ma, J.A.; Cahard, D. Angew. Chem. Int. Ed. 2004, 43, 4566-4583.

[13]. Dalko, P.I.; Moisan, L. Angew. Chem. 2004, 116, 5248-5286.

[14]. Dalko, P. I.; Moisan, L. Angew. Chem. Int. Ed. 2004, 43, 5138.

[15]. Shibasaki, M.; Yoshikawa, N. Chem. Rev. 2002, 102, 2187-2210.

[16]. Pihko, P.M. Angew. Chem. 2004, 116, 2110-2113.

[17]. Pihko, P.M. Angew. Chem. Int. Ed. 2004, 43, 2062-2064.

[18]. Seayad, J.; List, B. Org. Biomol. Chem. 2005, 3, 719-724.

[19]. Schreiner, P.R. Chem. Soc. Rev. 2003, 32, 289-296.

[20]. Takemoto, Y. Org. Biomol. Chem. 2005, 3, 4299-4306.

[21]. Taylor, M.S.; Jacobsen, E.N. Angew. Chem. 2006, 118, 1550-1573.

[22]. Taylor, M.S.; Jacobsen, E.N. Angew. Chemie. Int. Ed. 2006, 45, 1520-1543.

[23]. Connon, S.J. Chem. Eur. J. 2006, 12, 5418-5427.

[24]. Doyle, A.G.; Jacobsen, E.N. Chem. Rev. 2007, 107, 5713-5743.

[25]. Okino, T.; Hoashi, Y.; Takemoto, Y. J. Am. Chem. Soc. 2003, 125, 12672-12673.

[26]. Okino, T.; Nakamura, S.; Furukawa, T.; Takemoto, Y. Org. Lett. 2004, 6, 625-627.

[27]. Maher, D.J.; Connon, S.J. J. Tetrahedron Lett. 2004, 45, 1301-1305.

[28]. Fuerst, D.E.; Jacobsen, E.N. J. Am. Chem. Soc. 2005, 127, 8964-8965.

[29]. Yoon, T.P.; Jacobsen, E.N. Angew. Chem. 2005, 117, 470-472.

[30]. Yoon, T.P.; Jacobsen, E.N. Angew. Chem. Int. Ed. 2005, 44, 466-468.

[31]. Li, B.-J.1; Jiang, L.; Liu, M.; Chen, Y.-C.; Ding, L.-S.; Wu, Y. Synlett. 2005, 603-606.

[32]. Okino, T.; Hoashi, Y.; Furukawa, T.; Xu, X.; Takemoto, Y. J. Am. Chem. Soc. 2005, 127, 119-125.

[33]. Hoashi, Y.; Okino, T.; Takemoto, Y. Angew. Chem. 2005, 117, 4100-4103.

[34]. Hoashi, Y.; Okino, T.; Takemoto, Y. Angew. Chem. Int. Ed. 2005, 44, 4032-4035.

[35]. Vakulya, B.; Varga, S.; Csámpai, A.; Soós, T. Org. Lett. 2005, 7, 1967-1969.

[36]. McCooey, S.H.; Connon, S.J. Angew. Chem. 2005, 117, 6525-6528.

[37]. McCooey, S.H.; Connon, S.J. Angew. Chem. Int. Ed. 2005, 44, 6367-6370.

[38]. Berkessel, A.; Cleemann, F.; Mukherjee, S.; Müller, T.N.; Lex, J. Angew. Chem. 2005, 117, 817-821.

[39]. Berkessel, A.; Cleemann, F.; Mukherjee, S.; Müller, T.N.; Lex, J. Angew. Chem. Int. Ed. 2005, 44, 807-811.

[40]. Berkessel, A.; Cleemann, F.; Mukherjee, S. Angew. Chem. 2005, 117, 7632-7635.

[41]. Berkessel, A.; Cleemann, F.; Mukherjee, S. Angew. Chem., Int. Ed. 2005, 44, 7466-7469.

[42]. Berkessel, A.; Mukherjee, S.; Cleemann, F.; Müller, T.N.; Lex, J. Chem. Commun. 2005, 1898-1900.

[43]. Wang, J.; Li, H.; Yu, X.; Zu, L.; Wang, W. Org. Lett. 2005, 7, 4293-4296.

[44]. Inokuma, T.; Hoashi, Y.; Takemoto, Y. J. Am. Chem. Soc. 2006, 128, 9413-9419.

[45]. Xu, X.; Furukawa, T.; Okino, T.; Miyabe, H.; Takemoto, Y. Chem. Eur. J. 2006, 12, 466-476.

[46]. Marcelli, T.; van der Haas, R.N.S.; van Maarseveen, J.H.; Hiemstra, H. Angew. Chem. 2006, 118, 943-945.

[47]. Marcelli, T.; van der Haas, R.N.S.; van Maarseveen, J.H.; Hiemstra, H. Angew. Chem. Int. Ed. 2006, 45, 929-931.

[48]. Cao, Y.-J.; Lu, H.-H.; Lai, Y.-Y.; Lu, L.-Q.; Xiao, W.-J. Synthesis. 2006, 3795-3800.

[49]. Cao, C.-L.; Ye, M.-C.; Sun, X.-L.; Tang, Y. Org. Lett. 2006, 2901-2904.

[50]. Zuend, S.J.; Jacobsen, E.N. J. Am. Chem. Soc. 2007, 129, 15872-15883.

[51]. Wang, B.; Wu, F.; Wang, Y.; Liu, X. J. Am. Chem. Soc. 2007, 129, 768-769. 
[52]. Dinér, P.; Nielsen, M.; Bertelsen, S.; Niess, B.; Jørgensen, K.A. Chem. Commun. 2007, 3646-3648.

[53]. Macaev, F. Natural $\alpha$-pinenes, carvones, 2-and 3-carenes as source of enantio-pure compounds. Chişinău, Tip. AŞM. 2011, 236 p.

[54]. Bets, L., Vlad, L., Macaev, F. Chem. J. Moldova. 2010, 5, 6-23.

[55]. Bets, L., Ribkovskaia, Z., Vlad, L., Pogrebno,i S., Galin, F., Macaev, F. Chem. J. Moldova. 2010, 5, p. $57-72$.

[56]. Macaev, F.Z.; Malkov, A.V. Tetrahedron. 2006, 62, 9-26.

[57]. Chuiko V.A., Vyglazov O.G. Russ. Chem. Rev., 2003, 72, 49-67.

[58]. Macaev, F. Cercetări în domeniul chimiei; Î.E.P. Ştiința: Chişinău, 1999, 66-92.

[59]. Salakhutdinov, N.F.; Barkhash, V.A. Russ. Chem. Rev., 1997, 66, 343-362.

[60]. Ho, T.L. Enantioselective Synthesis Natural Products from Chiral Terpenes. NY, Chichester, Brisbane, Toronto, Singapore. John Wiley\&Sons, Inc. 1992, 324 p.

[61]. Ho, T.L. Carbocycle Construction in Terpene Synthesis. Weinheim, NY, Basel, VCH. 1988, 768 p.

[62]. Brown, H.C.; Ramachandran, P.V. Acc. Chem. Res. 1992, 25, 16-24.

[63]. Gavrilov, K.N.; Benetsky, E.B.; Grishina, T.B.; Zheglov, S.V.; Rastorguev, E.A.; Petrovskii, P.V.; Macaev, F.Z.; Davankov, V.A.. Tetrahedron: Asymmetry. 2007, 18, 2557-2564.

[64]. Gavrilov, K.N.; Benetskii; E.B.; Macaev; F.Z.; Davankov; V.A. Russ. J. Coord. Chem., 2007, 33, $230-231$.

[65]. Benetsky, E.B.; Zheglov, S.V.; Grishina, T.B.; Macaev, F.Z.; Bet, L.P.; Davankov V.A.; Gavrilov, K.N. Tetrahedron Lett. 2007, 48, 8326-8330.

[66]. Radul, O.; Gudima, A.; Macaev, F., Chem. J.Moldova. 2009, 4, 78-81.

[67]. Gudima, A. PhD thesis, Chisinau, 2008.

[68]. Macaev, F.; Radul, O.; Gudima, A. Russ. Chem.Bull. 2008, 7, 1343-1346.

[69]. Macaev, F.; Radul, O.; Gdanets, M. J.; Malinovskii, V.T. J. Struc.Chem. 2006, 4, 803-805.

[70]. Macaev, F.; Rusu, G.; Pogrebnoi, S.; Gudima, A.; Stingaci, E.; Vlad, L.; Shvets, N.; Kandemirli, F.; Dimoglo, A.; Reynolds, R. Bioorg. Med. Chem. 2005, 13, 4842-4850.

[71]. Macaev, F.; Ribkovskaia, Z.; Pogrebnoi, S.; Boldescu, V.; Rusu, G.; Shvets, N.; Dimoglo, A.; Geronikaki, A.; Reynolds, R. Bioorg. Med. Chem. 2011, 19, 6792-6807.

[72]. Lipinski, C.A.; Lombardo, F.; Dominy, B.W.; Feeney, P.J. Adv. Drug. Del. Rev. 2001, 46, 3-26.

[73]. Donova, M.N.; Nikolayeva, V.M.; Dovbnya, D.V. Microbiology. 2007, 153, 1981-1992.

[74]. Boldescu, V.; Bratu, I.; Borodi, Gh.; Kacso, I.; Bende, A.; Duca, Gh.; Macaev, F.; Pogrebnoi, S.; Ribkovskaia, Z. J. Incl. Phenom. Macrocycl. Chem. 2011, 71, 1-7.

[75]. Macaev, F.; Gavrilov, K.; Muntyanu, V.; Styngach, E.; Vlad, L.; Bets, L.; Pogrebnoi, S.; Barba, A. Chem. Natural Compounds. 2007, 43, 136-139.

[76]. Sargorovschi, V.; Sucman, N.; Iudin, T.; Duca, D.; Stingaci, E.; Prodius, D.; Pogrebnoi, S.; Macaev, F. Chem. J. Moldova. 2010, 5, 36-56.

[77]. Macaev, F.; Stingaci, E.; Munteanu, V. Design of new "ionic liquids" for liquid/liquid extraction of persistent toxic substances. In book "Soil Chemical Pollution, Risk Assessment, Remediation and Security. Springer Science. 2008, 223-228.

[78]. Macaev, F.; Munteanu, V.; Stingaci, E.; Barba, A.; Pogrebnoi, S. Chem. J. Moldova. 2007, 2, 119-122.

[79]. Horvath, A. Synthesis. 1994, 2, 102-105.

[80]. Macaev, F.; Styngach, E.; Muntyanu, V.; Pogrebnoi, S.; Rybkovskaya, Z.; Barba, A. Russ. J.Org. Chem. 2007, 43, 1512-1515.

[81]. Macaev, F.Z.; Styngach, E.; Shargarovskii, V.; Bets, L.; Vlad, L.; Barba, A. Russ. J.Org. Chem. 2010, 46, 610611.

[82]. Путилова, Е.С.; Крышталь, Г.В.; Жданкина, Г.М.; Троицкий, Н.А.; Злотин, С.Г. Журнал. Орг. Химии. 2005, 41, 524-528.

[83]. Wang, Z.; Wang Congna; Bao, W.; Ying, T. J. Chem. Research. 2005, 6, 388-390.

[84]. Makaev, F.Z.; Vlad, L.A.; Bets, L. P.; Malinovskii, S.T.; Gavrilov, K.N.; Gdanets, M. Chem. Natural Compounds. 2010, 46, 528-533.

[85]. Khan, A.T.; Parvin, T.; Choudhary, L.H. J. Org. Chem. 2008, 73, 8398-8402. 